\title{
Open Innovation and Stakeholder Engagement
}

\author{
Robert Wayne Gould
}

\begin{abstract}
The paradox of open innovation lies in the conflict between the practical desire to reap the benefits of open innovation and concern over the risk that others will misappropriate those benefits. Stakeholder theory and recent developments in value creation through stakeholder engagement can assist with reconciliation of this inherent structural risk. The limitations of existing open innovation typologies are identified, and a process-based model of open innovation is proposed. The model is then expanded to include stakeholder engagement. When integrated with stakeholder engagement, open innovation processes can be understood to generate benefits beyond the acquisition of specific information sought from external experts. The addition of stakeholder engagement to the open innovation model allows for greater understanding and easier acceptance of the risks inherent in the open innovation process.
\end{abstract}

Keywords: open innovation; paradox; stakeholder engagement; misappropriation; knowledge leakage; collaboration. 


\section{Introduction}

The logical underpinnings of the field of open innovation are based on the innovating organization's need to establish links that are external to the organization (Vanhaverbeke, 2006). For Chesbrough, (2003a, 2003b), the concept's original champion, the need for open cycles of innovation has become increasingly essential, if not inevitable. As knowledge has become the key resource in the post-industrial society (Bell, 1973), continued reliance solely on internal innovation processes has become a practical impossibility. Open innovation then represents the logical result of dramatic social, technological, and environmental change.

The practice-based origins of the open innovation concept highlight a structural tension. The practical desire to reap the potential benefits of open collaboration stands in conflict with concern over the risk that other institutional actors may misappropriate those benefits. The methodology of openness implies an inherent lack of control, both of the processes themselves, and of the potential results (Mahr, Rindfleisch, and Slotegraaf, 2010). Participants in open innovation processes risk the loss, both intentional and unintentional, of the very fruits of their efforts to other participants in the network they have created (Wadhaw, Bodas-Fritas, and Sarkar, 20l I). As it is the very nature of the open innovation process itself that creates this paradox, the resulting tensions are both structural and pervasive.

Stakeholder theory (Freeman, 1984; Freeman, Harrison, and Wicks 2007; Freeman, et al., 20I0), especially recent work focusing on the significance of stakeholder engagement (Svendsen, 1998; Zadek, 200I; Noland and Phillips, 2010), is offered to inform development of a model that addresses this inherent conflict in open innovation processes. Consideration of the social, organizational, and ethical benefits of engagement with relevant stakeholders enhances the concept of open innovation, helping to move beyond its solely practice-based origins.

This paper proceeds in two steps. First, the relationships that create the risks inherent in open innovation are identified and explored, in an effort to further advance understanding of the underpinnings of open innovation; a processbased model of open innovation is then advanced. Second, the processes of stakeholder engagement are linked to those of open innovation and are integrated into the open innovation model. The integration of stakeholder engagement into the process model helps point to a way to accept, if not completely reconcile, the tensions inherent in the very structure of open innovation processes.

\section{Open Innovation}

Organizational efforts at innovation are simultaneously driven by the need, and the opportunity, to improve products and processes. O'Sullivan and Dooley $(2009$, p. I) define innovation as "the process of making changes to something established by introducing something new that adds value to customers." Since the possibilities of established "somethings" that can be improved are effectively infinite, innovation plays a continuous role in every aspect of organizational experience.

Chesbrough (2003a, 2003b) characterizes the change from closed to open models of innovation as no less than a paradigm shift. In the old paradigm, closed innovation, successful innovation requires the organization to exert substantial internal control on all aspects of the process. The new paradigm, open innovation, holds in contrast that successful innovation requires significant integration of both internal and external components. While critics (Trott and Hartmann, 2009) argue that the differences in closed and open are really more evolutionary than transformational, the adoption of the open innovation concept over the past decade cannot be denied (Giannopoulou, et al., 2010; Huizingh, 20II; Lichtenthaler, 20I I).

The effective "inevitability" of the advance of open innovation is based in the substantial changes that have occurred in the operating environment. Organizations want to access, develop, absorb, or commercialize new technologies; the pace of technological change has increased dramatically. The roles of organizational knowledge and of knowledge workers have acquired increasing importance (Savino, 2009); knowledge has become the key resource in the post-industrial society (Bell, 1973). The speed and intensity of change insures both that more information is needed, and that it must be acquired at a progressively faster pace. Workers are more mobile in terms of employment and thus organizational affiliation; as they move, they take their knowledge and ideas with them. Accordingly, the maintenance of closed cycles of innovation through rigid internal control has become increasingly difficult (Vanhaverbeke, 2006). The open view is in greater harmony with the new "landscape of abundant knowledge" (Chesbrough, 2003b, p. 37); it therefore becomes a superior strategic approach under new evolving conditions.

\section{Open Innovation and Strategic Opportunity}

The closed approach to innovation was ideally structured to meet the operating environment represented in the traditional view of organizational strategy (Porter, 1980, 1985). In the traditional view of strategy, only a given number of product positions are likely to be successful and an even

ISSN: 07 I8-2724. (http://www.jotmi.org)

Journal of Technology Management \& Innovation (c) Universidad Alberto Hurtado, Facultad de Economía y Negocios. 
smaller number sustainable in the face of competitive forces. Organizational/product positioning within an industry is of singular importance; position must be designed to create and maintain competitive advantage. Industry structure is defined in terms of the now well-known "five forces" (Porter, 1980, p. 4): potential entrants, buyers, substitutes, suppliers, and industry competitors; this structure determines the nature of competition within the industry. There are then three possible generic positions to hold in response to the five competitive forces: cost leadership, differentiation, and focus (Porter, 1980). Innovation in this view is constrained by the specific industry structure and the organization's chosen positioning strategy. This means that the processes of innovation must be fairly strictly directed and controlled, as only certain types of innovations are likely to be useful in advancing the chosen organizational strategy. Under conditions that support successful long-term maintenance of specific positions of competitive advantage, closed innovation was the logical innovation process.

Under on-going conditions of dramatic change in operating environments, however, periods of market equilibrium become shorter and shorter. In the absence of lengthy periods of market stability, it becomes more and more difficult to maintain the traditional fixed positions of competitive advantage (D'Aveni, 1994). Advantage is fleeting; it continuously erodes, often as quickly as it is created. Organizations need to innovate constantly in order to capture new positions of competitive advantage. Rather than accepting existing structures, successful organizations now reorder industry boundaries and by constructing new configurations generate increased demand and create new markets (Kim and Mauborgne, 2005, 2009). Under these conditions, strategy must be seen, in and of itself, as a process of innovation. It becomes more difficult to hold on to advantage long enough to pay for significant internal R\&D investment and for those processes to generate innovations with sufficient speed. Since strategy must be constantly revisited and reformulated in order to capture new positions of advantage in advance of continuous forces of change, an exclusive reliance on internal R\&D and closed innovation processes no longer makes strategic sense.

In order to successfully pursue innovation as strategy, organizations then need to develop external linkages, leveraging opportunities to access innovative ideas outside organizational boundaries, that is, through open innovation. Open innovation allows access to the aggregation of the knowledge of the other players in the process; the innovating organization "discovers locations in the landscape that it may never have reached had it been in charge of all choices" (Almirall and Casadesus-Masanell, 2010, p. 44).
The linkages that access external experts and comprise the open innovation systems can take a number of forms. Vanhaverbeke (2006, p. 205) defines the relationships simply in terms of the "ties of innovating firms with other organizations." The participants in open innovation can also be described variously as a network of experts (Rohrbeck, 2010) or a community of practice (Yström, et al., 20I0). The open innovation relationship could be with an organization, or with individual actors, who may or may not formally represent their employing institution (West and O'Mahony, 2008). The open innovation relationship could also include involvement with external experts, linked to the organization through an "on-line external innovation broker" (Mahr, et al., 2010 , p. 4). Participants could be included from universities, from the public sector, from competitors, from suppliers, from customers, and from other industries (Bogers, 20II; Jarvenpaa and Wernick, 20I I; Maehler, et al., 20II). The external experts possess specific knowledge and understandings that the focal organization needs to access.

\section{Open Innovation, External Interactions, and Appropriability}

Perhaps as a natural result of enthusiasm for a newly formulated concept, the existing literature on open innovation has been focused much more extensively on the benefits than on the costs, disadvantages, and limitations (Dahlander and Gann, 20I0). de Wit, Dankbaar, and Vissers (2007) found that cost-cutting in corporate research departments can make it more difficult to manage innovation inbound to the organization, thus limiting the effectiveness of open innovation. As well, Laursen and Salter (2006b) found that returns to openness were non-linear, and that accordingly there may at some point be diminishing returns to maintaining an open posture.

Regardless of the somewhat limited discussion in the literature, the possibility that innovating firms may not always capture the returns from their innovations is clearly entwined with the opportunities of open innovation. Lichtenthaler and Frishammar (20lI) note that even conscious decisions to release knowledge to competitors, as in the case of licensing proprietary technology, carry the risk of strengthening the competition. Mohamed et al., (2007) argue that knowledge leakage can be either positive or negative; it is simply a consequence of internal and external knowledge flows. Using this definition in the context of open innovation, however, positive knowledge leakage of information into the innovating organization can be simply seen as the goal of the process. This leaves the consideration of negative knowledge leakage. The risk of negative knowledge leakage is that "sole ownership of knowledge leaks away from the origin and may lead to a loss of competitive advantage" (Mohamed, et al., 2007, p. 459). 
As Teece's (1986) foundational work predates Chesbrough's (2003a, 2003b), he does not consider open innovation specifically. But, if imitators can successfully appropriate the profits, then there is logically no organizational incentive to innovate, via either open or closed processes. Teece (1986) defines appropriability as the range of environmental factors that impact the innovator's ability to capture the profits from the innovation. The formal structures of appropriability are encompassed by the legal protections afforded in intellectual property law (Blaxill and Eckardt, 2009). A variety of organizational strategies can be employed in an attempt to capture appropriability and prevent the loss of key information from the focal organization to the open innovation network, including secrecy, first mover advantage, and design complexity (West, 2006).

Fear of knowledge leakage, as Laursen and Salter (2006a, p. 7) argue, can drive organizations to develop a "myopia of protectiveness," with excessive focus on secrecy and the legal protection strategies. Fear of knowledge leakage can drive organizations to avoid interactions that involve knowledge sharing all together (Myers and Cheung, 2008), and thus forgo the open innovation process altogether.

\section{Models of Open Innovation}

Duarte and Sarkar (20II, p. 437) correctly note the definitions in the field of open innovation are unclear and the field overall suffers from a "proliferation of terms." Theoretical modeling in open innovation has been limited, and when occurring, has been dominated by efforts that identify structural categories, with insufficient attention being paid to industry- (Ozman, 20II) and culture-specific (Savitskaya, Salmi, and Torkkeli, 2010) aspects of processes and inter- actions. For example, Dahlander and Gann (2010) first separate inbound and outbound innovation, then further subcategorizing each by the evidence of direct financial involvement. Similarly, van de Vrande et al. (2009) separate open innovation processes into categories of exploration and exploitation, using the terms exploration and exploitation to represent inflows and outflows. Lichtenthaler and Lichtenthaler (2009) identify open innovation processes as knowledge exploration, knowledge exploitation, and knowledge retention, and further break these categories into internal or external. This categorization generates a total of six categories of organizational capacity, with inventive, transformative, innovative, as internal and absorptive, connective, and desorptive as external.

Where should concepts of risk be placed within the development of a theory of open innovation? The literature on open innovation has generally considered the existence of paradoxical tensions simply as polarized conflicts in need of resolution (Jarvenpaa and Wernick, 20I I). However, recent work in paradox theory (Lewis, 2000; Lewis and Smith, 20II) emphasizes understanding paradox as representing the involved demands of extremely complicated operating environments. Thus, recognizing and accepting the existence of paradox supports the understanding and management of inherently contradictory aspects in the organizational experience.

Models based on categorizations do not prove particularly useful, however, for use in evaluating the issue of risk in open innovation. Rather, since the risk of misappropriation occurs as a result of the processes of open innovation, development of a process-based model becomes critical for the evaluation of structural risk in open innovation. Such a

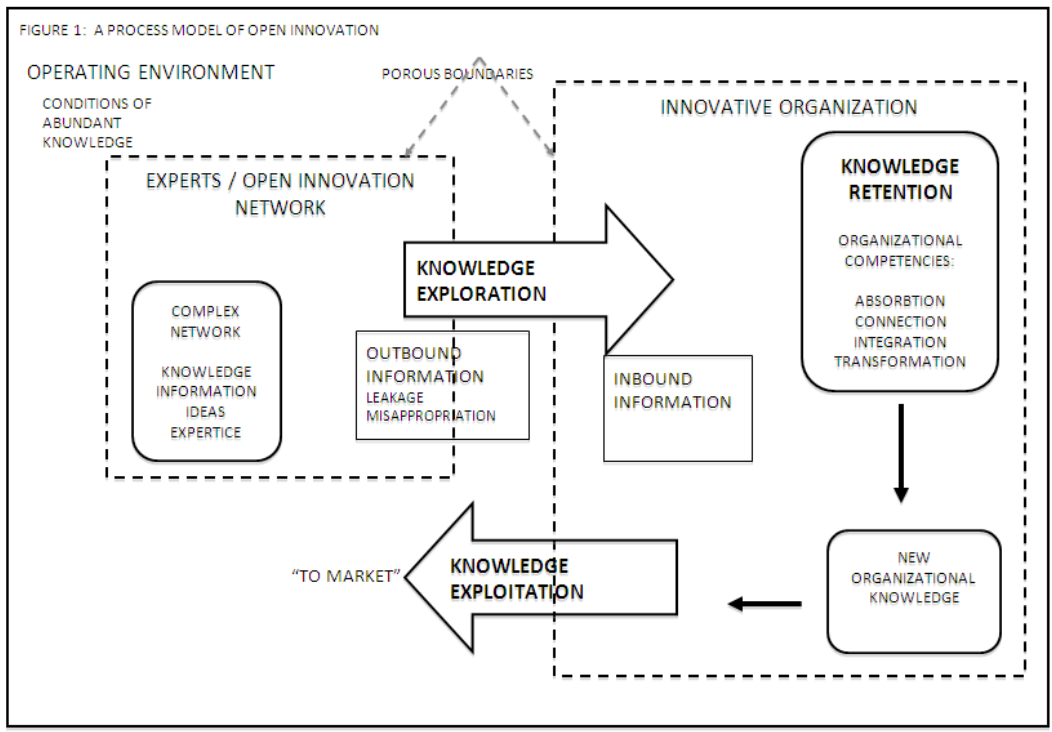

Figure I

ISSN: 07I 8-2724. (http://www.jotmi.org)

Journal of Technology Management \& Innovation (C) Universidad Alberto Hurtado, Facultad de Economía y Negocios. 
process-based, rather than category-based, model of open innovation is offered in Figure I. The categorization distinguished by Lichtenthaler and Lichtenthaler (2009, p. I 3 I7) of knowledge "exploration" (inbound), knowledge "retention" (within organization) and knowledge "exploitation" (outbound) serves as a starting point for the new model.

In the process-based model, however, the nature and direction of organization-environment relationships become the focus of consideration. The innovating organization, and the experts that comprise the innovation network are shown as occupying places in the operating environment. The experts are loosely formed into a complex network, with porous boundaries, which in reality should be even less clearly defined than in the figure. The organization seeks inbound information; there may be inadvertent leakage of information outbound or missapropriation of the innovations developed. Within the innovative organization, the inbound information is absorbed, connected, integrated, and transformed into knowledge that can be retained by the organization. This new organizational knowledge may then be exploited through delivery to the market.

\section{Stakeholder Theory}

Freeman's (1984) foundational work identified the importance of the role of stakeholders in relationship to the organization. Multiple players interact with the organization; those stakeholders must be taken into account by the organization when facing complex conditions in the operating environment. Freeman's (1984, p. 25) initial, and still widely accepted, definition of a stakeholder was "any group or individual who can affect or is affected by the achievement of the firm's objectives." From this definition, a model was developed showing the firm at the center of a broad range of stakeholder groups. More recent refinements show a two tiered mapping, categorizing some stakeholder groups as primary, those that "define" the business, with an outer secondary ring of players that can impact the relationships with the primary grouping (Freeman, et al., 2007). Primary stakeholders include groups such as communities, customers, employees, suppliers, and financiers; secondary stakeholders include groups such as government, competitors, consumer advocate groups, social-interest groups, and media. The processes of identification of relevant stakeholders can involve formal efforts as stakeholder mapping (Bourne and Walker, 2005). Fassin (2008) comprehensively identifies the broad range of types of complex interactions and relationships that can be captured in such mapping processes. Mitchell, Agle, and Wood's (1997) typology for identifying salient stakeholders, based on managerial perception of three factors -- power, legitimacy, and urgency -- has been quite broadly adopted. In more recent work, Mitchell et al. (20II) reaffirmed those factors as keys to identification and categorization.
Effective use of stakeholder theory as an analytical tool also requires evaluation of the nature of multiple interactions and interdependencies between and among stakeholder groups. Frooman (1999, p. 192) argues for the importance of evaluating "multi-actor" relationships. Rowley (1997) links stakeholder theory to social network theory, and in doing so identifies a range of possible network configurations. Roloff (2008) expands on Rowley's (1997) model, applying the network approach to evaluating cooperative partnerships among multiple stakeholders. Lamberg et al., (2008) argue for the significance of path-dependence in stakeholder relationships, identifying the importance of both initial conditions and the sequence of events that transpire. Zietsma and Winn (2008) consider the idea that some stakeholders can attempt to link with others in efforts to improve relative position. Accordingly, networks of stakeholder relationships can be complex and nuanced and participants in a stakeholder network (Lewrick, Raeside, and Pelsi, 2007) may have significant interaction with other participants outside of the control of the focal organization.

\section{Stakeholder Engagement}

Freeman's (1984) original conception of the importance of stakeholders was strategic in nature. Over the intervening decades, the concept has been expanded to consider a substantially broader range of social and ethical implications (Freeman, et al., 2007; Freeman, et al., 2010). Freeman and his associates' most recent work advocates for capturing the strategic and ethical benefits of authentic interaction with the full range of organizational stakeholders. In this view, strategic concerns and moral ones cannot ultimately be separated, as the purpose of the system of capitalism and the players within it is "the creation of value for all stakeholders" (Noland and Phillips, 2010, p. 40).

The importance of comprehensive value creation, in contrast with the traditional focus solely on profit maximization, has not only been developed in the stakeholder literature, but has recently been raised in both the areas of marketing (Smith, Drumwright, and Gentile, 2010) and strategy (Maas and Boons, 2010; Porter and Kramer, 20II). Rather than simply placating stakeholders and developing buffers to protect against the uncertainty of the complex external environment, engagement promotes the development of collaboration and shared goals (Svendsen, 1998; Andriof and Waddock, 2002). Successful organizational leadership develops stakeholder networks and links with the range of external stakeholders (Maak, 2007). Gao and Zhang (2006, p. 725) see engagement as a "developmental exercise" that enhances "mutual understanding." Communication helps to build higher quality organization-stakeholder relationships (Antonacopoulou and Meric, 2005). Ayuso et al. (201 I) emphasize the importance of interacting with secondary

ISSN: 07 I8-2724. (http://www.jotmi.org)

Journal of Technology Management \& Innovation @ Universidad Alberto Hurtado, Facultad de Economía y Negocios. 
stakeholders when accessing information to drive innovation processes. Engagement can be seen, then, as a practical method for the development of on-going relationships with relevant stakeholders (Smith, Ansett, and Erez, 20II), key in the implementation of value creation (Baden, 20l0).

Simultaneously with relationship building, stakeholder engagement allows the organization to access information from its stakeholders (Sharma, 2005). This knowledge can then be used to generate approaches that successfully impact operations and profitability, that is, to create value. Katsoulakos and Katsoulacos (2007) argue that the existence of "advantage-creating stakeholder relations" support organizational knowledge development. Similarly, Nelson and Zadek (2000) argue that engagement creates an "alchemy" of relationships, where resources experience transformation as well as simply being combined. Accordingly, Ayuso, Rodríguez, and Ricart (2006) view the ability to integrate the knowledge obtained from stakeholders as an organizational competency.

In this context, Freeman and his associates advance stakeholder engagement as a "principle" -- simply, "a large cast of stakeholders is necessary to sustain value creation" (Freeman, et al., 2010, p. 282); the result of the stakeholder engagement process is that taking ethically correct actions brings positive economic results. Organizations create sustainable value by developing as many win-win situations with those stakeholders as possible. The better the understanding of the stakeholders' needs and desires, the easier it becomes to create the win-win situations (Plaza-Úbeda, et al., 2009). Organizations simultaneously build positive relationships and effective strategy through stakeholder engagement.

\section{Open Innovation and Stakeholder Engagement}

Open innovation and stakeholder engagement describe similar organizational processes. In both cases, the focal organization reaches outside its boundaries making an explicit effort to access essential information. Yet the two concepts, and their associated languages and discussions, have remained isolated from each other.

Figure 2 represents a preliminary effort to integrate the processes of stakeholder engagement into the model of open innovation. As the innovative organization undertakes knowledge exploration by engagement with stakeholders in the open innovation network, the process of knowledge exploration is transformed. Seen in this light, the process requires that the innovating organization must offer information outbound, as well as seeking information inbound, as represented by the two-ended arrow found in the center of the figure. The outbound information may leak into the network in unforeseen and unexpected ways. Similarly, the inbound information may create value in unforeseen and unexpected ways. Dialogue and relationship building become key elements of the knowledge exploration process, expanding beyond the singular focus on information extraction. The creation of organizational value is emphasized in the knowledge retention process, while the creation of social value is emphasized in the knowledge exploitation process.

\section{Discussion}

The paradox of open innovation lies in the conflict between the potential benefits of collaboration and the prospects of knowledge leakage and misappropriation of the results of

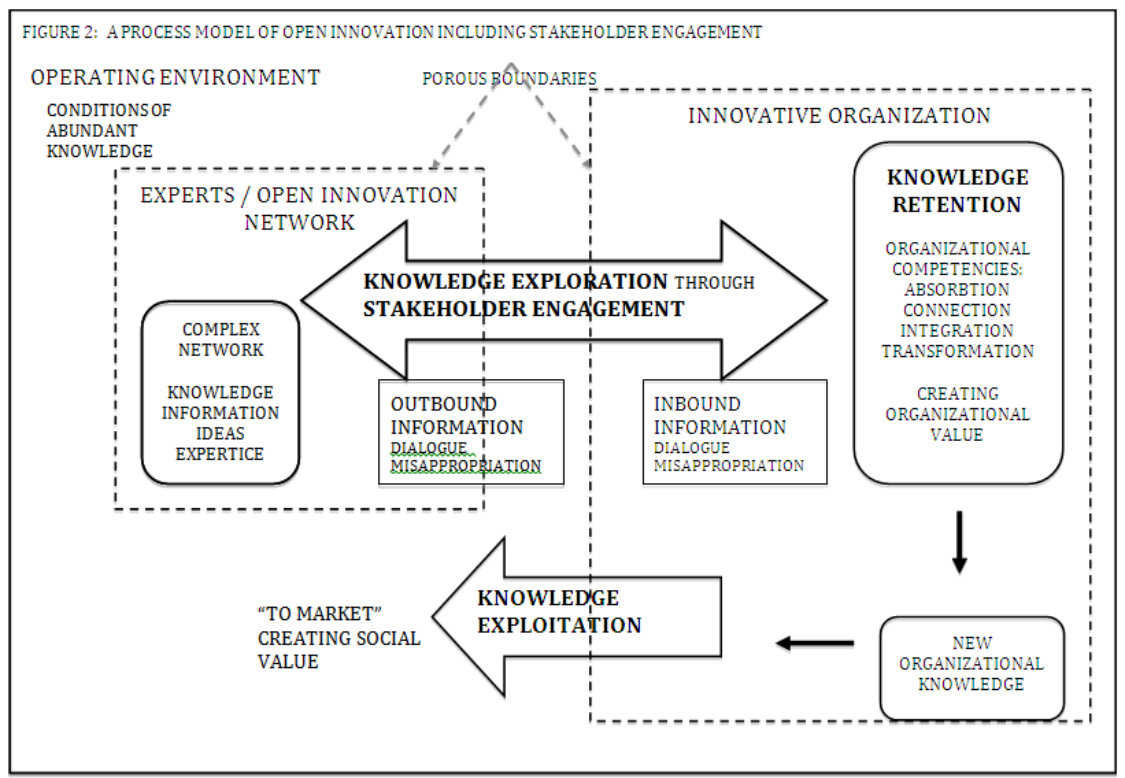

Figure 2

ISSN: 07 I8-2724. (http://www.jotmi.org)

Journal of Technology Management \& Innovation (c) Universidad Alberto Hurtado, Facultad de Economía y Negocios. 
the process. These concerns represent a conflict of requirements. The very linkages that are essential to the open innovation process may cause the organization to lose control of specific information. This knowledge, in the hands of a competitor, could compromise the new position of competitive advantage potentially gained from the open innovation process if accessed by competitors.

The open innovation model is substantially more complex than the old approach of closed innovation; "open innovation includes many more activities than just those that were assigned to a traditional R\&D department" (van de Vrande, et al., 2009, p. 425). Involvement within the open innovation process requires interaction and disclosure; information may be revealed to the expert network whether this was or was not the intention of the innovating organization. Such information could be about the nature of the problem, the knowledge retained, or the solution generated. The experts in the open innovation process are part of an extended network; participants in the network may have significant interaction with other participants outside of the control of the innovating organization. Network participants may be involved with a range of possible organizations, and may, in their role in the open innovation project, be representing the interests of their organization to a greater or lesser extent. This complexity of relationships increases the probability of the unintended leakage within and beyond the open innovation network.

In order for open innovation to be effective, organizations must also have sufficient capability to successfully integrate the information obtained from the external sources into internal processes and structures (Nonaka, 2007). Integrative abilities of this type are essential competencies for the modern learning organization (Senge, 2006). Building relationships through stakeholder engagement enhance the organizational competencies necessary to accomplish knowledge retention and knowledge exploitation (Ayuso, et al., 2006). By integrating concepts from stakeholder engagement with open innovation, the risk of open innovation is contextualized to include benefits beyond the specifics of expert knowledge initially sought. Engagement involves processes of dialogue (Waddock, 200I), and result in relationship development. Information flow occurs in both directions; while knowledge may inadvertently seep out of the focal organization it may inadvertently seep in as well. Stakeholder engagement supports an emphasis on accountability as well as performance (Gao and Zhang, 200I). The emphasis in relationship building supports a focus on value creation. The risks of inadvertent knowledge leakage and misappropriation can now be seen in the context of the benefits of the development of relationship and dialogue.

\section{Future Research and Conclusion}

The preliminary model presented here opens significant opportunities for future research. First, there is opportunity for more detailed identification and analysis of specific processes involved in both open innovation and stakeholder engagement, including the role of intellectual property and other organizational protections, the impact of specific network configurations, the roles of power, legitimacy, and urgency, and the roles of specific development paths. Second, traditional stakeholder categorizations do not necessarily capture the unique groupings of stakeholders that can be involved in the process. Stakeholders in the open innovation process are not always easily categorized as primary or secondary, as the nature of the market relationships of network participants can vary and individual stakeholders may operate with or without organizational clear affiliation. Thus, further attention should be paid to defining and mapping the specifics of stakeholder relationships and engagement processes in the context of open innovation processes. Third, as Greenwood (2007) has noted, the concept of stakeholder engagement is not morally unambiguous. Engagement may not represent honest or authentic interaction, but may simply represent efforts at co-optation. Accordingly, the issue of organizational intention in the open innovation process needs to be considered in the model as well. Fourth, significant opportunities also exist to apply the process model of open innovation including stakeholder engagement to empirical verification.

Organizational experience can involve the experience of inherently contradictory aspects (Lewis, 2000; Smith and Lewis, 20l I). The idea of open innovation makes inherent emotional sense; it should "work" to share and openly engage with experts within and outside of organizational boundaries. The structural tension between the potential benefits of such collaboration and the risks that other institutional actors will misappropriate the results, however, creates the paradox of open innovation. Integrating recent developments in stakeholder theory with a process-based view of open innovation helps point in the direction of greater understanding of these structural risks, as well as providing ways to think about their reconciliation. 


\section{References}

ANDRIOF, J.,Waddock, S. (2002). Unfolding stakeholder engagement. In:Andriof, J., Waddock, S., Husted, B., Sutherland, R.S. (Eds.), Unfolding Stakeholder Thinking: Theory, Responsibility and Engagement, Vol. I. Greenleaf Publishing Limited, Sheffield, pp. 19-42.

ANTONACOPOULOU, E.P., Meric, J. (2005). From power to knowledge relationships: Stakeholder interactions as learning partnerships. In: Bonnafous-Boucher, M., Pesqueux Y. (Eds.), Stakeholder Theory: A European Perspective. Palgrave Macmillan, New York, pp. I25- 147.

AYUSO, S., Rodríguez, M.A., García-Castro, R., Ariño, M.A. (20II). Does stakeholder engagement promote sustainable innovation orientation? Industrial Management and Data Systems, III, I399-I4I7.

AYUSO, S., Rodríguez, M.A., Ricart, J.E. (2006). Responsible competitiveness at the "micro" level of the firm: Using stakeholder dialogue as a source for new ideas: A dynamic capability underlying sustainable innovation. Corporate Governance, 6(4), 475-490.

BADEN, D. (2010). CSR: An opportunity for SMEs. In: Louche, C., Idowu, S. O., Filho, W. L. (Eds.), Innovative CSR: From risk management to value creation. Greenleaf Publishing Limited, Sheffield, pp. 84- I0I.

BELL, D. (1973). The Coming of Post-industrial Society: A Venture in Social Forecasting. Basic Books, New York.

BLAXILL, M., Eckardt, R. (2009). The Invisible Edge: Taking Your Strategy to the Next Level Using Intellectual Property. Penguin Group, New York.

BOGERS, M. (20II). The open innovation paradox: knowledge sharing and protection in $\mathrm{R}$ and $\mathrm{D}$ collaborations. European Journal of Innovation Management, I4(I), 93-I I7.

BOURNE, L., Walker, D.T. (2005). Visualising and mapping stakeholder influence. Management Decision, 43(5), 649-660.

CHESBROUGH, H.W. (2003a). Open Innovation: The New Imperative for Creating and Profiting from Technology. Harvard Business School Press, Boston.

CHESBROUGH, H.W. (2003b). The era of open innovation.

MIT Sloan Management Review, 44(3), 35-4I.

DAHLANDER, L., Gann, D. M. (2010). How open is innovation? Research Policy, 39(6), 699-709.
D'AVENI, R.A. (1994). Hypercompetition: Managing the Dynamics of Strategic Maneuvering. The Free Press, New York.

DE WIT, J., Dankbaar, B.,Vissers, G. (2007). Open innovation: The new way of knowledge transfer?. Journal of Business Chemistry, 4(I), II-19.

DUARTE, V.V., Sarkar, S.S. (20I I). Separating the wheat from the chaff: A taxonomy of open innovation. European Journal of Innovation Management, I4(4), 435-459.

FASSIN, Y. (2008). Imperfections and shortcomings of the stakeholder model's graphical representation. Journal of Business Ethics, 80(4), 879-888.

FREEMAN, R.E. (1984). Strategic Management:A Stakeholder Approach. Pitman, Boston.

FREEMAN, R.E., Harrison, J.S.,Wicks, A.C. (2007). Managing for Stakeholders: Survival, Reputation, and Success. Yale University Press, New Haven.

FREEMAN, R.E., Harrison, J.S., Wicks, A.C., Parmer, B. L., de Colle, S. (2010). Stakeholder Theory: The State of the Art. Cambridge University Press, Cambridge.

FROOMAN, J. (1999). Stakeholder influence strategies. Academy of Management Review, 24(2), I9|-205.

GAO, S.S., Zhang, J.J. (200I). A comparative study of stakeholder engagement strategies in social auditing. In:Andriof, J., Mclntosh, M. (Eds.), Perspectives on Corporate Citizenship. Greenleaf Publishing Limited, Sheffield, pp. 239-255.

GAO, S.S., Zhang, J.J. (2006). Stakeholder engagement, social auditing and corporate sustainability. Business Process Management Journal, I2(6), 722-740.

GIANNOPOULOU, E., Yström, A., Ollila, S., Fredberg, T., Elmquist, M. (2010). Implications of openness: A study into (all) the growing literature on open innovation. Journal of Technology Management \& Innovation, 5(3), 162-180.

GREENWOOD, M. (2007). Stakeholder engagement: Beyond the myth of corporate responsibility. Journal of Business Ethics, 74(4), 3I5-327.

HUIZINGH, E.K.R.E. (20I I). Open innovation: State of the art and future perspectives. Technovation, $3 \mathrm{I}(\mathrm{I}), 2-9$.

JARVENPAA, S.L.,Wernick,A. (20II) Paradoxical tensions in open innovation networks. European Journal of Innovation Management, I4(4), 52I-548. 
KATSOULAKOS, T., Katsoulacos, Y. (2007). Integrating corporate responsibility principles and stakeholder approaches into mainstream strategy: A stakeholder-oriented and integrative strategic management framework. Corporate Governance, 7(4), 355-369.

KIM,W.C., Mauborgne, R. (2005). Blue Ocean Strategy: How to Create Uncontested Market Space and Make the Competition Irrelevant. Harvard Business School Press, Boston.

KIM, W.C., Mauborgne, R. (2009). How strategy shapes structure. Harvard Business Review, 87(9), 72-80.

LAMBERG, J., Pajunen, K., Parvinen, P., Savage, G.T. (2008). Stakeholder management and path dependence in organizational transitions. Management Decision, 46(6), 846-863.

LAURSEN, K., Salter,A. (2006a). My Precious:The role of appropriability strategies in shaping innovative performance.

DRUID Working Paper 05-02. www.druid.dk/uploads/tx_ picturedb/wp05-02.pdf [Accessed May 2, 20I2].

LAURSEN, K., Salter, A. (2006b). Open for innovation: The role of openness in explaining innovation performance among UK manufacturing firms. Strategic Management Journal, 27(2), |3|-| 50.

LEWIS, M. (2000). Exploring paradox:Toward a more comprehensive guide. Academy of Management Review, 25(4), $760-776$.

LEWRICK, M., Raeside, R., Peisl, T. (2007). The innovators's social network. Journal of Technology Management \& Innovation, 2(3), 38-48.

LICHTENTHALER, U. (20II). Open innovation: Past research, current debates, and future directions. Academy of Management Perspectives, 25(I), 75-93.

LICHTENTHALER, U., Frishammar, J. (201 I). The impact of aligning product development and technology licensing: $A$ contingency perspective. Journal of Product Innovation Management, 28(SI), 89-103.

LICHTENTHALER, U., Lichtenthaler, E. (2009). A capability-based framework for open innovation: Complementing absorptive capacity. Journal of Management Studies, 46(8), 1315-1338.

MAAK, T. (2007). Responsible leadership, stakeholder engagement, and the emergence of social capital. Journal of Business Ethics, 74(4), 329-343.
MAAS, K., Boons, F. (20I0). CSR as a strategic activity: Value creation, redistribution and integration. In: Louche, $C$., Idowu, S. O., Filho, W. L. (Eds.), Innovative CSR: From risk management to value creation. Greenleaf Publishing Limited, Sheffield, pp. 154-I 72.

MAEHLER, A.E., Curado, C.M.M., Pedrozo, E.Á., Pires, J.P. (20II). Knowledge transfer and innovation in Brazilian multinational companies. Journal of Technology Management \& Innovation, 6(4), I-I3.

MAHR, D., Rindfleisch, A., Slotegraaf, R.J. (2010). Innovation Beyond Firm Boundaries: The Routines and Resource Investment of Successful External Problem Solvers. Paper presented at American Marketing Association Winter Educators' Conference, New Orleans, LA, February 19-22. http:// ebookbrowse.com/rindfleisch-background-paper-march20 I0-pdf-d I385945 I 9 [Accessed May 2, 20I2].

MITCHELL, R.K.,Agle, B.R., Chrisman, J.J., Spence, L.J. (20I I). Toward a theory of stakeholder salience in family firms. Business Ethics Quarterly, 2 I (2), 235-255.

MITCHELL, R.K., Agle, B.R., Wood, D. J. (1997). Toward a theory of stakeholder identification and salience: Defining the principle of who and what really counts. Academy of Management Review, 22(4), 853-886.

MOHAMED, S., Mynors, D., Grantham,A., Chan, P., Coles, R., Walsh, K. (2007). Unearthing key drivers of knowledge leakage. International Journal of Knowledge Management Studies, I (3/4), 456-470.

MYERS, M.B., Cheung, M.-S. (2008). Sharing global supply chain knowledge. MIT Sloan Management Review, 49(4), 6673.

NELSON, J., Zadek, S. (2000). Partnership Alchemy: New Social Partnerships in Europe. The Copenhagen Centre, Copenhagen.

NOLAND, J., Phillips, R. (2010). Stakeholder engagement, discourse ethics and strategic management. International Journal of Management Reviews, 12(I), 39-49.

NONAKA, I. (2007). The knowledge creating company. Harvard Business Review, 85(7/8), 162-171.

O’SULLIVAN, D., Dooley, L. (2009). Applying innovation.

SAGE Publications, Inc, Thousand Oaks.

OZMAN, M. (20II). Modularity, industry life cycle and open innovation. Journal of Technology Management \& Innovation, 6(I), 26-37. 
PLAZA-ÚBEDA, J.A., Burgos-Jiménez, J.J.,Vazquez, D.A., Liston-Heyes, C.C. (2009). The 'win-win' paradigm and stakeholder integration. Business Strategy and the Environment, 18(8), 487-499.

PORTER, M.E. (1980). Competitive Strategy: Techniques for Analyzing Industries and Competitors. Free Press, New York.

PORTER, M.E. (1985). Competitive Advantage: Creating and Sustaining Superior Performance. Free Press, New York.

PORTER, M.E., Kramer, M.R. (20I I). Creating shared value. Harvard Business Review, 89(I/2), 62-77.

ROHRBECK, R. (2010). Harnessing a network of experts for competitive advantage: technology scouting in the ICT industry. $R$ and D Management, 40(2), I69-180.

ROLOFF, J. (2008). Learning from multi-stakeholder networks: Issue-focused stakeholder management. Journal of Business Ethics, 82(I), 233-250.

ROWLEY,T.J. (1997). Moving beyond dyadic ties:A network theory of stakeholder influences. Academy of Management Review, 22(4), 887-910.

SAVINO, D.M. (2009). The role of technology as an enabler in job redesign. Journal of Technology Management \& Innovation, 4(3), 14-23.

SAVITSKAYA, I., Salmi, P.,Torkkeli, M. (20I0). Barriers to open innovation: Case China. Journal of Technology Management \& Innovation, 5(4), 10-2I.

SENGE, P.M. (2006). The Fifth Discipline: The Art and Practice of the Learning Organization. (Rev. ed.) Currency/Doubleday, New York.

SHARMA, S. (2005). Through the lens of managerial interpretations: Stakeholder engagement, organizational knowledge and innovation. In: Sharma, S., Aragón-Correa, J.A. (Eds.), Environmental Strategy and Competitive Advantage. Edward Elgar Academic Publishing, Northampton, pp 49-70.

SMITH, N.C., Ansett, S., Erez, L. (20I I). How Gap Inc. engaged with its stakeholders. MIT Sloan Management Review, 52(4), 69-76.

SMITH, N.C., Drumwright, M.E., Gentile, M.C. (2010). The new marketing myopia. Journal of Public Policy and Marketing, 29(I), 4-II.
SMITH,W.K., Lewis, M.W. (20I I). Toward a theory of paradox:A dynamic equilibrium model of organizing.Academy of Management Review, 36(2), 38I-403.

SVENDSEN, A. (1998). The Stakeholder Strategy: Profiting from Collaborative Business Relationships. Berrett-Koehler Publishers, Inc, San Francisco.

TEECE, D.J. (1986). Profiting from technological innovation: Implications for integration, collaboration, licensing, and public policy. Research Policy, I5(6), 285-305.

TROTT, P., Hartmann, D. (2009). Why 'Open Innovation' is old wine in new bottles. International Journal of Innovation Management, I3(4), 7I5-736.

VAN DE VRANDE, V., de Jong, J.P..., Vanhaverbeke, W., de Rochemont, M. (2009). Open innovation in SME's: Trends, motives and management challenges. Technovation, 29(6/7), 423-437.

VANHAVERBEKE, W. (2006). The interorganizational context of open innovation. In: Chesbrough, H, Vanhaverbeke, W., West, J. (Eds.), Open Innovation: Researching a New Paradigm. Oxford University Press, New York, pp. 205-219.

WADDOCK, S. (200I). Integrity and mindfulness: Foundations of corporate citizenship. In: Andriof, J., Mclntosh, M. (Eds.), Perspectives on Corporate Citizenship. Greenleaf Publishing Limited, Sheffield, pp. 26-38.

WADHAW, A., Bodas-Fritas, I.M., Sarkar, M.B. (20II). The Paradox of Being Open: External Technology Sourcing and Knowledge Protection. Paper presented at the Dynamics of Institutions and Markets (DIME) Final Conference, Maastricht, Netherlands, April 6-8. final.dime-eu.org/files/BodasFreitas_etal_E3.pdf [Accessed May 2, 20I2].

WEST, J. (2006). Appropriability and open innovation. In: Chesbrough, H., Vanhaverbeke, W., West, J. (Eds.), Open Innovation: Researching a New Paradigm. Oxford University Press, New York, pp. 109-I33.

WEST, J., O'Mahony, S. (2008). The role of participation architecture in growing sponsored open source communities. Industry and Innovation, I5(2), I45-168.

YSTRÖM,A., Ollila, S., Fredberg,T., Elmquist, M. (2010). Communities of practice for open innovation: Enabling organizational creativity? Proceedings of the 7th International Conference on Intellectual Capital, Knowledge Management and Organizational Learning, 524-530.

ZADEK, S. (200I). Partnership alchemy: Engagement, innovation and governance. In:Andriof, J., Mclntosh, M. (Eds.), 
Perspectives on corporate citizenship. Greenleaf Publishing Limited, Sheffield, pp. 200-2/4.

ZIETSMA, C.,Winn, M. (2008). Building chains and directing flows: Strategies and tactics of mutual influence in stakeholder conflicts. Business and Society, 47(I), 68-10I. 